\title{
アルミニウム合金基複合材料の変形特性に及ぼす マトリクス不均質ミクロ組織の影響の数值解析
}

\author{
戸田裕之小林俊郎井上直也 \\ 豊橋技術科学大学生産システム工学系
}

J. Japan Inst. Metals, Vol. 61, No. 2 (1997), pp. 120-127

\section{Numerical Analysis of Effects of Inhomogeneous Matrix Microstructures on Deformation Characteristics in Aluminum Matrix Composites}

Hiroyuki Toda, Toshiro Kobayashi and Naoya Inoue ${ }^{\dagger}$

Department of Production Systems Engineering, Toyohashi University of Technology, Hibarigaoka,

Tenpaku-cho, Toyohashi-city, Aichi 441

Recently it has been reported that PFZ layers, ranging several ten and $100 \mathrm{~nm}$ in thickness, and coarse interfacial equiribrium precipitates were formed around reinforcements, and that solute atoms were simultaneously segregated toward the interface. In this study, $\mathrm{SiC}$ whisker-reinforced 6061 Aluminum alloys are adopted as model materials. Effects of such locally-inhomogeneous microstructures of a matrix on the deformation and fracture characteristics of the MMCs are analyzed by means of the elastic-plastic finite element analysis.

Due to the ductile nature of the PFZ layers, the concentrated plastic flow within the PFZ layers increases the effective plastic strain in the whole matrix, thereby reducing the strength of the MMCs. On the other hand, the interfacial precipitates effectively retard the concentrated plastic flow within the PFZ layers and consequently suppress the reduction in strength due to the formation of the PFZ. However, the interfacial precipitates never exhibit such preferable influence when the matrix is homogeneous.

Both the axial stress within the whiskers and the initiation rate of voids due to the strain concentration around edges of the whiskers increase with extension of the PFZ layers and the interfacial precipitates. The initiation rate of the void is remarkably affected by the morphology and density of the precipitates. Since both the shear stress at the precipitate-reinforcement interface and the internal stresses within the precipitates are considerably high, the properties of the precipitates except for Young's modulus are important.

Interphase having intermediate Young's modulus remarkably improves the strength of the MMCs.

(Received October 23, 1996)

Keywords: finite element analysis, metal matrix composite, stress strain curve, precipitate free zone, segregation, interfacial precipitates, interphase, void nucleation rate

\section{I．緒言}

'90年代に入って，MMC 母相のミク口組織の特徵につい て，いくつかの新しい知見が報告されている．例壳ば， $\mathrm{SiC} / 6061 \mathrm{Al}$ 合金系では，強化材を取り囲む幅 40〜60 nm の PFZ (Precipitate free zone) 層之界面上の数 $\mathrm{nm}$ 数十 $\mathrm{nm}$ の 粗大な平衡析出物が観察されている(1). 同様な報告は, $\mathrm{Al}$ $\mathrm{Cu}-\mathrm{Mg}$ 合金(2)，Al-Zn-Mg-Cu 合金(3) 和よび Al-Li-Mg-Si 合 金(4)を母相とする $\mathrm{MMC} て ゙ る$ 報告されている。市た， $\mathrm{PFZ}$ が形成される界面近傍では，溶質原子の非平衡偏析が生じる ことが確諗されている(2)(5)。この他，アルミニウム合金基の

$†$ 豊橋技術科学大学大学院生, 現在 : サッポ口産機(做)(Graduate Student, Toyohashi University of Technology. Present address: Sapporo Sanki Co. Ltd..)
MMC以外でも，Ti-Al-Nb 基の MMCに拈ける強化材近傍 の及年層はよく知られており ${ }^{(6)}$ ，局所的に変質した不均 一なミクロ組織は，MMC 母相のごくありふれた組䅧形態で めるといら認識が必要である。

著者らは, 最近, 強化材周国の $\mathrm{PFZ}$ 層や溶質原子の偏析 が MMC の変形特性化及ぼす影響を，弾塑性有限要素法で 解析した(7).これによれば，幅わずか 44 ないし $88 \mathrm{~nm}$ とい ら薄層の PFZ が強化村周囲に形成されることで, 母相の広 い領域にわたって有効塑性ひずみが影著に増加し，巨視的な 比例限以降で強度が $4 \sim 7 \%$ 程度低下する。

一方，強化材表面に析出や化学反応などにより生成した粒 子が MMCの変形破壊挙動に及ばす影響に関しては，推測 に基ついた感覚的な議諭が多く，力学的に十分解明されてい ないのが現状である。そこで本研究では，PFZ層や溶質原 子の扁析に加苀て，界面に粒子が付着した場合の変形特性 
を，弾塑性有限要素法によって数值解析する。

\section{II. 実験および数值計算の方法}

\section{1. 有限要素法解析モデル}

解析対象としたそデル材料は，これまで著者らが力学的性 質を実験などにより確認した $22 \% \mathrm{SiC}$ ウスカー $/ 6061 \mathrm{Al}$ 複合材料で兆る(1)(5)(7)-(12).

解析モデルでは，ウィスカーが無限体中で負荷応力方向に 配向し，上下左右に整列しているすのと仮定した(side-byside model)．またモデルは，セルの二本の対称軸を利用し て1/4モデルとし，平面焉み条件で解析した。

強化材の配列様式を規定するセルの周期対称性条件は, 隣 接セルとの幾何学的整合性から次の上ら設設定した。

$$
\begin{array}{ll}
\partial u_{z} / \partial r=0, & \text { on } z=l_{c} \\
\partial u_{r} / \partial z=0, & \text { on } r=r_{c}
\end{array}
$$

ここで， $u_{i}$ は $i$ 方向の変位成分である。また， $r$ 拉よび $z$ は セルの半径方向乱よび軸方向の座標軸を表し， $l_{c}$ 乱よび $r_{c}$ はセルの半長扒よび半径である。

また，一つのセルの対称条件は，次式の上らになる。

$$
\begin{array}{ll}
u_{r}=0, & \text { on } r=0 \\
u_{z}=0, & \text { on } z=0
\end{array}
$$

ウィスカーの平均アスペクト比: $l_{w} / r_{w}$ は，モデル材料か ら酸洗いによって抽出した SiCウィスカーの笑測值である 13.7 とし, 平均直径: $2 r_{w}$, 体積率: $l_{w} r_{w} / l_{c} r_{c}$ は, 同じく元 れぞれ $440 \mathrm{~nm}, 22.0 \%$ とした ${ }^{(8)}$ 。また，セルのアスペクト 比 $l_{c} / r_{c}$ は, Dutta らによる検討の結果(13)を参考にして，4.9 に設定した。な拉，この上らに強化材の平均サイズを用いた 解析の妥当性汇ついては, Takao と Taya が議論してい $る^{(14)}$.

解析モデルでは，前報で大きな応力勾配が確認されたウれ スカー内部々 PFZ 層特よびその周辺の母相領域は細かく, そこから $r$ 方向および $z$ 方向には, それぞれ1.069倍批よび 1.049倍ずつ順次要素の一辺の長さを粗くし, 二次元四節点 四角形要素を用いて分割した。最小の要素サイズは 22 $\mathrm{nm} \times 22 \mathrm{~nm}$, 総節点数は 4347 となった。 また, 要素数中分 割は, Fig. 1 の各モデルで同一である. 分割数に関しては, 前報之同様见 ${ }^{(7)}$, 要素数を增加させながら計算を行って正解 への収束性を検討して決定した。

Fig. 1 K示す四つのモデルは, 解析に用いた基本的なも デルである。まず, Basic model は，従来から検討されてい るウィスカーと均一なアルミニウム合金母相のみのモデルで ある. 他のモデルの $\mathrm{PFZ}$ 層幅, 析出物のサイズと分布密度 の值は, 実験観察による定量解析結果(1)-(4)をるとに決定し た.この場合, PFZ層は, ウィスカーの外周に沿って均一 な厚みを持つものとした. PA model と表記したものは, 最 高時効状態の観察結果をもとに決定したものであり, PFZ 層幅 $44 \mathrm{~nm}$, 析出物サイズ $22 \mathrm{~nm} \times 22 \mathrm{~nm}$, 析出物のウィス カー表面積に対する被覆率は9.7\%で崩る。また， $\mathrm{OA}$



(a)

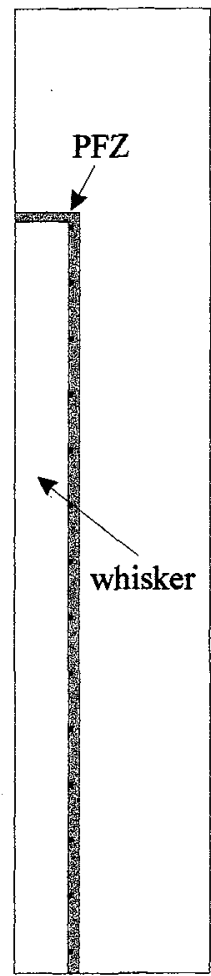

(b)

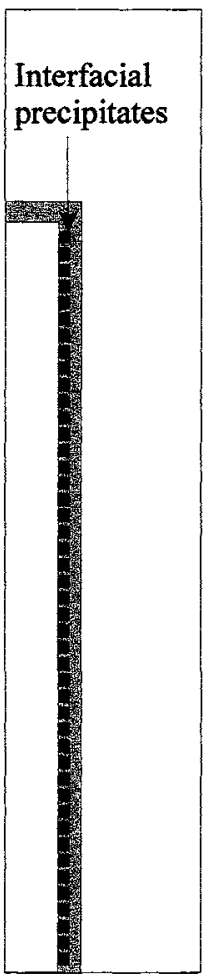

(c)
Fig. 1 Schematic illustration of quarter models. (a) Basic model, (b) PA model and (c) OA model.

model は過時效状熊に相当し, PFZ 層幅 $90 \mathrm{~nm}$, 析出物サ イズ $44 \mathrm{~nm} \times 44 \mathrm{~nm}$ ，被覆率 $66 \%$ である.PA(No PFZ) model は, PA model から PFZ 層を除去したものであり, 析出物の影響を抽出して検討するために用いた。 また，析出 物サイズの影響を検討するため，OA model に括いては $\mathrm{OA}$ (Coarse) model 打よび OA(Fine) model として, 析出物 幅をそれぞれ $68 \mathrm{~nm}, 22 \mathrm{~nm}$ としたモデルを作成した。

計算に用いた $\mathrm{SiC}$ ウィスカーおよび $\mathrm{PFZ}$ 層内外の母相の 真応力-真歪曲線衫上び各物性值は前報(7)の Fig. 2 特よび Table 1 と同じで㐫る.PFZ領域には析出物が存在せず, 最大で5.5\%程度に達するマグネシウム原子の濃化が生じて いることから (5)，PFZ層中の母相はすべて $\mathrm{Al}-6 \% \mathrm{Mg}$ 合金 の○材の応力-歪曲線(15)炕したがって变形すると仮定した。

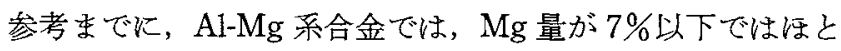
几ど析出が生じないと報告されている(16)。るた， PFZ層以 外の領域の母相の応力-歪曲線は, OA model も含めて, す べて6061合金の $\mathrm{T} 6$ 最高時効状態のものを用いた，析出物に ついては，モデル材で界面に析出する $\mathrm{Mg}_{2} \mathrm{Si}$ 平衡相を想定 し，ヤング率: $120 \mathrm{GPa}, v: 0.27$ とした(17). また，強化村表 面の粒子のヤング率の影響を検討するため， $\mathrm{Al}-\mathrm{Mg}$ 系合金 を母相とし， $\mathrm{Al}_{2} \mathrm{O}_{3}$ ないしはその複合酸化物で強化した $\mathrm{MMC}$ 等で, 反応生成することが報告されているスピネル $\left(\mathrm{MgAl}_{2} \mathrm{O}_{4}\right)$ を想定し, 粒子のヤング率を $260 \mathrm{GPa}^{(18)}$ 亿变更 した計算も行った。以下，このモデルを $\mathrm{PA}\left(\mathrm{MgAl}_{2} \mathrm{O}_{4}\right)$ 
model と呼ぶことにする。

さらに，ウィスカー周囲の中間層が，PFZのような軟質 母相ではなく, 強化材と母相の中間程度の弾性率を有する場 合の計算を行った. Interphase model と呼ぶこのモデルの 中閒層の弾性率は $200 \mathrm{GPa} と し$, 層厚さは PA model と同 じ $44 \mathrm{~nm}$ とした。このような中間層は，強化材へのューテ ィング処理層, 製造工程や熱処理工程で生じる母相-強化材 間の反応生成相として，実用材料でもしばしば観察されるも のである。

\section{2. 解析方法}

モデル材料では，微細なウィスカーが均一かつ高密度に分 布しているため，母相中の転位の移動はウィスカーによって 阻止されて，変形は比較的均一になる．したがって，今回の 計算では，母相の結晶塑性の異方性は考慮していない.

母相は，時間依存性のない変形挙動を示す弾塑性体と乙。 変形中も完全中実体を保つと仮定した．母相の塑性変形の開 始を規定する降伏条件には，次式のvon Misesの条件を採 用した。

$$
f\left(\sigma_{i j}\right)=J_{2}^{\prime}-1 / 3 \sigma_{y}^{2}=0
$$

ここで, $J_{2}^{\prime}$ は偏差応力: $\sigma_{i j}$ の二次不变量であり， $\sigma_{y}$ は Mises の相当降伏応力である．また，降伏後の母相は，等方 的に加工硬化するるのとした。

塑性歪増分と応力増分の関係を決定する流孔則には，塑性 歪增分が塑性ポテンシャルと呼ばれる量：Qの応力勾配に 比例するとする次式の結合流れ則を用いた。

$$
\left(\mathrm{d} \varepsilon_{i j}\right)_{\mathrm{p}}=\mathrm{d} \lambda \partial Q / \partial \sigma_{i j}
$$

ここで, $\left(\mathrm{d} \varepsilon_{i j}\right)_{\mathrm{p}}$ は塑性歪増分, $\mathrm{d} \lambda$ は塑性比例係数であり, 正の值をとる。 また，構成方程式の非線形関係の解法は， Newton-Raphson 法によった.

\section{III. 計 算 結 果}

\section{1. 応力-歪曲線}

Fig. 2 は, Basic model, PA(No PFZ) model, PA model 扣よび OA model の真応力-真歪曲線の計算結果をまとめた 子のである. Basic model 火界面析出物のみを追加した PA(No PFZ) model では，析出物の追加によって, 比例限 以降の応力がごくわずかに上昇するものの，医 Basic model と同等である。また，PFZ を設定した PA model 贸 よび OA model では，Basic model よりも明らかに強度が低 下している、ただし，PA model と OA model の差は顕著で はなく、むしろ PA model の方が若干低い結果となった。

Fig. 3 は，OA model 基準とし，析出物のサイズを変化 させた結果である。析出物サイズの桩大に伴い，明らかに比 例限以降の強度が向上している。特に，析出物サイズを PFZ 層厚さの76\%とした OA (Coarse) model では，顕著な 強度の改善が認められる。

Fig. 4 は, PA model の界面粒子のヤング率を，120から
$260 \mathrm{GPa}$ に増加させて計算した結果である。ヤング率を約 2.2倍に増加させても，応力-歪曲線への影響は法とんど認め られない。

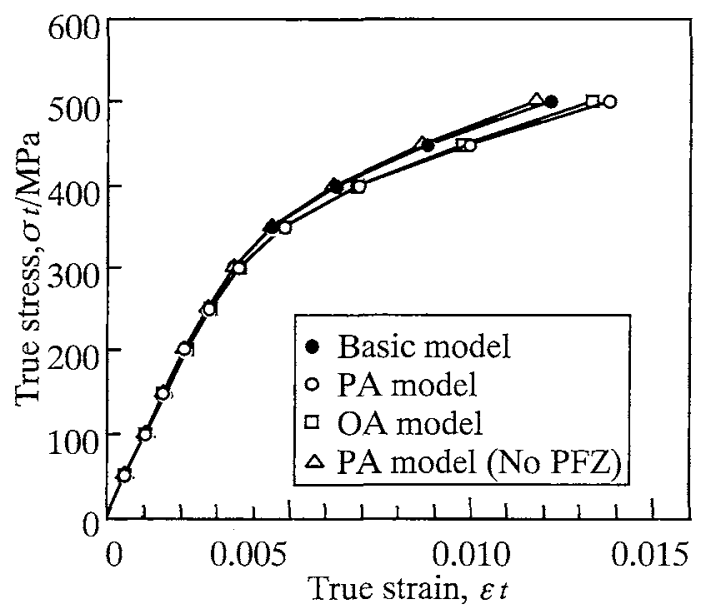

Fig. 2 Effects of precipitate size and PFZ layer thickness on the stress-strain curves of the $6061 \mathrm{Al}-22$ vol\% $\mathrm{SiC}$ composites.

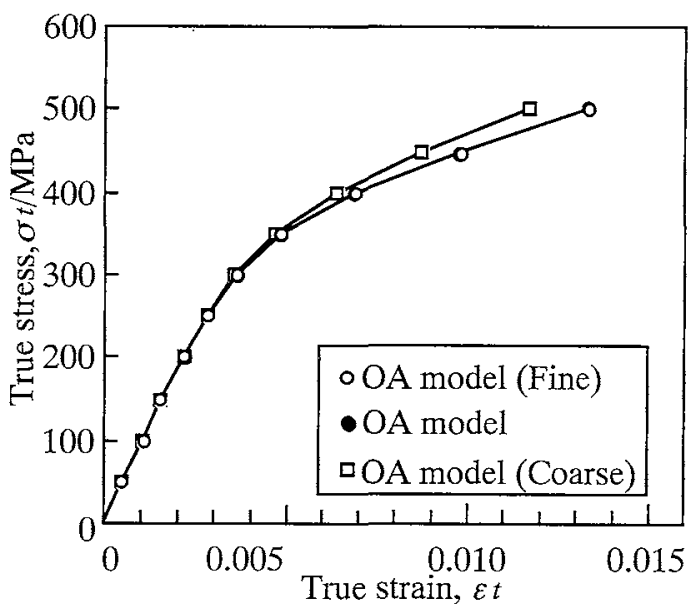

Fig. 3 Effects of precipitate size on the stress-strain curves in the OA model.

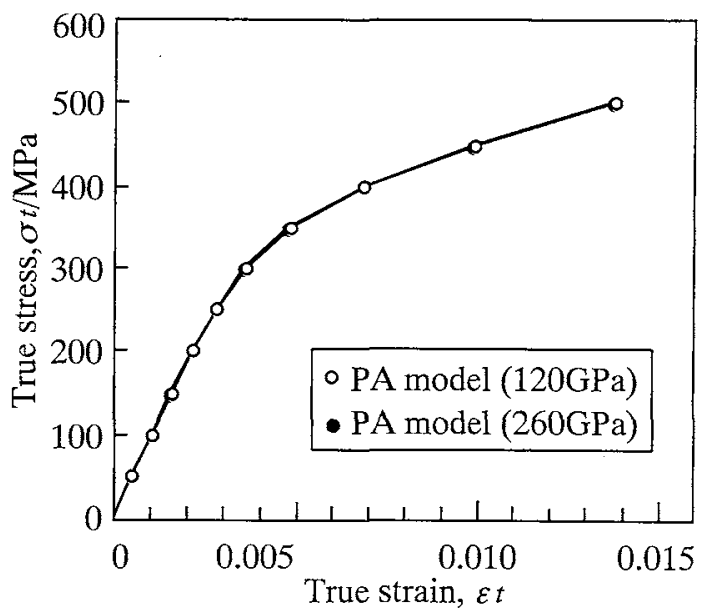

Fig. 4 Effects of elastic modulus of the precipitates on the stress-strain curves in the PA model. 


\section{2. 微視的な応力, 歪の分布}

Fig. 5 は，応力-歪曲線で差異が認められた Basic model, PA model, OA model 特よび OA (Coarse) model で, ウィス カ一内の負荷応力方向の軸応力を比較した等高線図である.

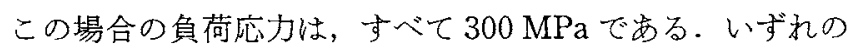
モデルでも，ウィスカ一長手方向中央部の表面付近で軸応力 は最大となっている。軸応力の最大値は, OA model で最も 高く, 以下 OA(Coarse) model, PA model, Basic model の順 に低下している。また，逆に，軸応力が $1.6 \mathrm{GPa}$ 以上の領 域は，Basic model で広く，他の 3 つのモデルは同程度で， 狭くなっている。

Fig. 6 は, Basic model, PA model 拉よび OA model に拉 ける、ウィスカー側面に沿う界面せん断応力を比較したもの である.いずれのモデルでも，ウィスカーの中心付近で界面 せ九断応力は低く，端部に近つくにつれて急激に上㫒してい る.PA modelでは，析出物の分布密度が低いために，析出 物の前後でせん断応力が鋭く変化している。また，PA model, OA model では，ウィスカー端部付近でのせん断応力 の最大值が，端部近い析出物による影響で上杽して和り， 特に PA model では，他のモデルと比較して14〜31\%も上 昇している。ただし，全体的な傾向は，PFZ層や析出物が 存在しても，注ぼ同様である。

Fig. 7 は, Basic model, PA model, OA model 脑び

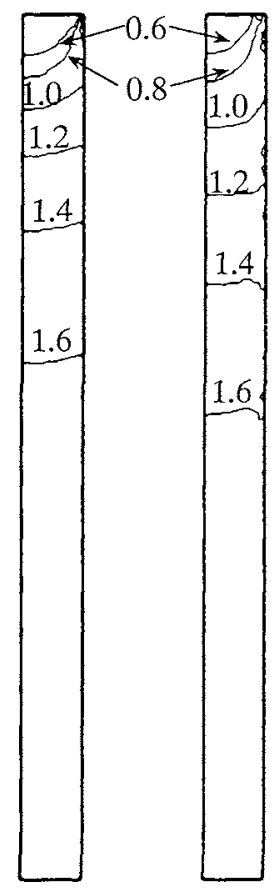

(a)

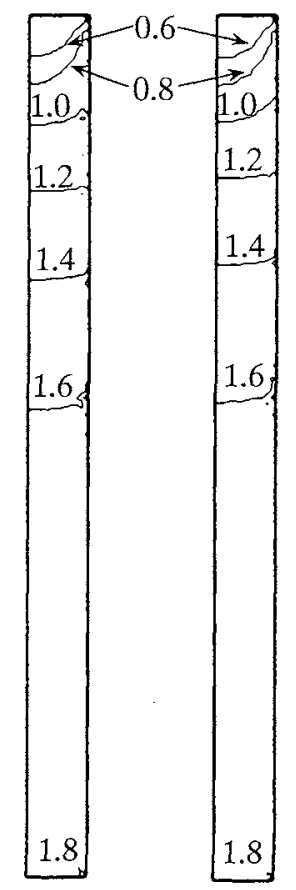

(c) (d)

(GPa)
Fig. 5 Contour maps of the axial stress, $\sigma_{z}$, within the whisker in the direction of the applied stress. (a) Basic model, (b) PA model, (c) OA model and (d) OA (Coarse) model. Applied stress, $\sigma_{a}$, is $300 \mathrm{MPa}$.
OA (Coarse) model で，母相内の相当塑性歪みの分布を示し たものである. Basic model, PA model, OA model と PFZ サイズが拡大するに伴って，前報と同㥞に，ウィスカー端部 近傍の高塑性歪み領域が顕著に拉大する(7)。また，PFZ内 だけではなく，その外側の母相の相当塑性正み飞も顕著な影 響が出る点は注目すべき点である。相当塑性歪みが最大值を 取る位置は，析出物がない場合にはウィスカー端部近傍です り，析出物がある場合は，Fig. 1 で最上部にある析出物の端 部となっている。

Fig. 8 は，PA(No PFZ) model, PA model 括よび OA model の析出物内の最大応力を比較したものである.PFZ のない PA(No PFZ) model では, PFZのある PA model と 比較して，析出物内の応力は明らかに低くなっている。一

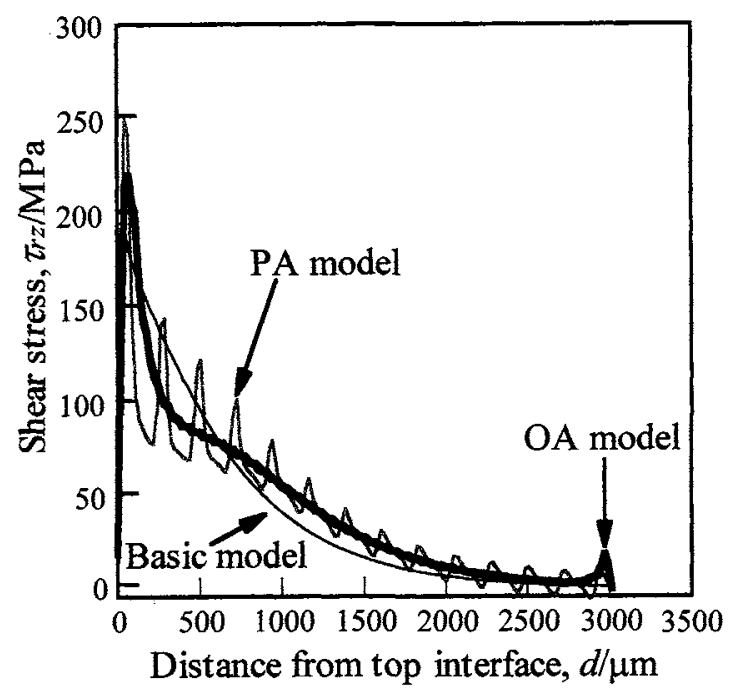

Fig. 6 Distribution of interfacial shear stress, $\tau_{r z}$, along the side surface of the whiskers. Applied stress, $\sigma_{a}$, is $300 \mathrm{MPa}$

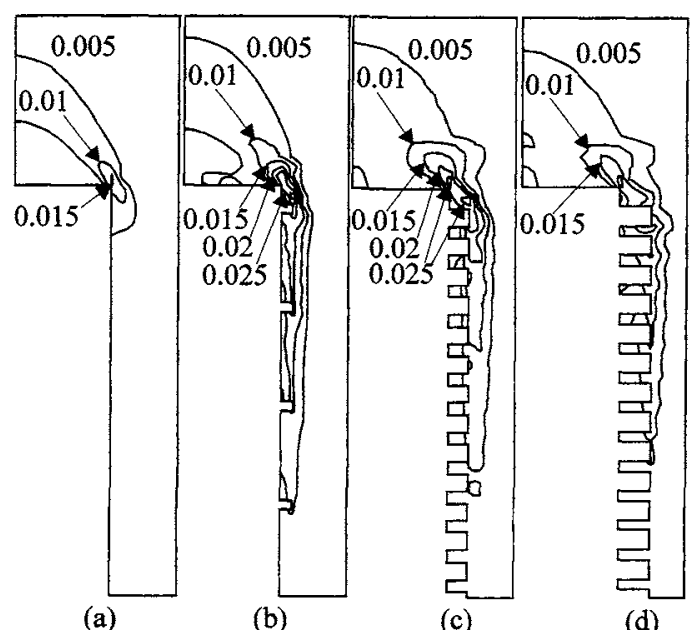

Fig. 7 Contour maps of the effective plastic strain, $\overline{\varepsilon_{p}}$, within the matrix. (a) Basic model, (b) PA model, (c) OA model and (d) OA (Coarse) model. 


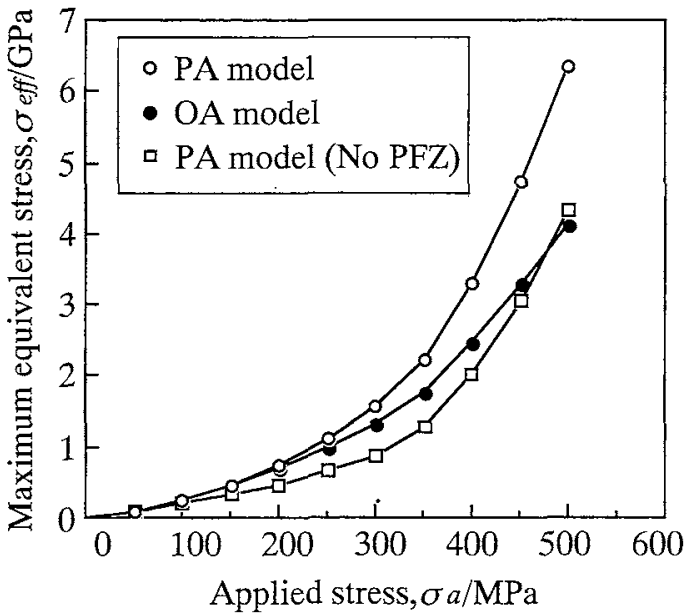

Fig. 8 Maximum equivalent stress, $\sigma_{\text {eff }}$, within the precipitates as a function of the applied stress, $\sigma_{a}$.

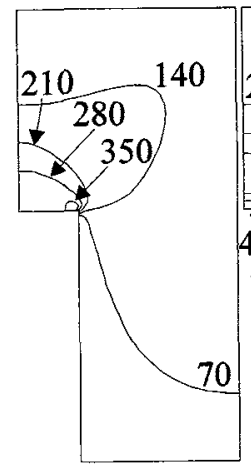

(a)

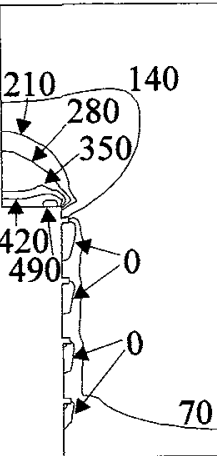

(b)



(c)
Fig. 9 Contour maps of the hydrostatic stress, $\sigma_{h}$, within the matrix. (a) Basic model, (b) PA model and (c) OA model. Applied stress, $\sigma_{a}$, is $300 \mathrm{MPa}$.

方, ウィスカー表面に対する被覆率が $9.7 \%$ と低いPA model では, OA model と比較してかなり大きな応力值を取 っている。また，いずれのモデルでも，負荷応力が 250 $\mathrm{MPa}$ 前後の時に析出物内部の応力が $1 \mathrm{GPa}$ 飞達している。

Fig. 9 は，母相中の静水压㡻力の分布を示寸等高線図で 西る. PA model 括よび OA model では, Basic model と比 較して，ウィスカ一端部近傍の静水圧応力の上昇が顕著であ ること，およびウィスカー中央部付近と側面付近に，静水圧 王縮の領域があることが特徵的である。ウィスカー端部での 静水压応力性, PA model で最も大きく, 応力が最大となる 位置は，ウィスカー上端面近傍となっている。委た，ウィス カ一側面で压縮の静水圧応力が発生する理由は, PA model の等高線図から明らかなように，PFZ 内の瀕著な塑性流動 を析出物が阻止するためである。

最後に，詳細は省略するが，Fig. 4 で示した析出物のヤン グ率の影響炕関する計算では, 負荷応力 $300 \mathrm{MPa}$ の段階で
析出物内の忘力は $40 \%$ 程度上昇するるのの，先机以外の母 相中の相当応力, 相当塑性歪み, 静水圧応力扰上びウィスカ



\section{3. 中間的な弾性率を有する Interphase の影響}

Fig. 10 は，ウィスカーと母相の中間程度の弾性率を有す る Interphase がある場合の応力-霆曲線である. Interphase model では, 本研究の他のモデルと比較して, 比例限以降の 応力が顕著に上昇している，また，母相中の相当塑性稬みや

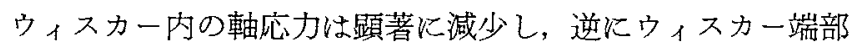
近傍の静水压応力や界面応力は大きく上昇することが確認さ れた。

\section{N，考察}

\section{1. 不均質母相が MMC の強度低下を招く機構の検討}

強化材に上る母相の塑性流動の拘束は, 応力三軸度の上昇 をもたらす。委た，界面での応力伝達によってもたらされる 強化材による負荷応力の分担恃，繊維が特に一方向配向した 複合材料では，しばしば主要な強化機構となる。しかしなが ら，前報の計算では，PFZ層の形成による強度低下の原因 としては，これら二つの機構は二次的な因子と判明した(7). 本研究の場合子, 静水圧応力, 界面せ九断応力, 繊維内軸応 力と強度の予測值には相関が認められず，上記二つの機構 は，変質したミクロ組織の影響を説明するものではないと結 論される.

PFZ層のみの影響を検討した前報では，低負荷応力段階 から始をる PFZ 層内の局所的な塑性变形が，母相の広い領 域にわたる塑性変形を促進し，強度を低下させることが明ら かとなった(7). 本研究で夕, Basic model, PA model, OA model の順で高 $\overline{\varepsilon_{p}}$ レベルの領域は㩆著に拡大しており,こ れは，前報と同様に PFZ 幅の影響と考穴られる。

また，析出物サイズの影響を OA model で検討すると，



Fig. 10 Effects of the interphase with intermediate Young's modulus around the whisker on the stress-strain curves. 
析出物の大きな OA(Coarse) model では，中程度のOA model と比較して, 高 $\overline{\varepsilon_{p}} レ$ レ゙ルの領域の面積および 大値は大幅に減少している。 $\overline{\varepsilon_{p}}$ の最大值で比較すると，負 荷応力 $400 \mathrm{MPa}$ 以上では，むしろ $\mathrm{PFZ}$ 層のないBasic model よりも低くなっている.このことから, 界面析出物は, PFZ 層内の塑性流動を有効に阻止し，PFZの形成に上る強 度低下を逆に排制する方向に働くと考えられる。たたし， PA(No PFZ) model のように PFZが存在しない場合には， 界面析出物は強度上昇注とんど寄与しない。

このように界面析出物が強度低下を抑制する力向に働くた めには，当然，析出物が低負荷応力で破壊または界面剝離し ないことが必要となる。なた，一般的なアルミニウム合金の 析出物と PFZ 組合孔を考方る限り，界面粒子の弾性率の 影響はあまり影著ではないことを，Fig.4 は示している。以 上の検討から，ある程度の破断強度之界面剂離強度を有する 粒子であれば，析出物，強化材-母相間の反応生成物，強化 材にあらかじめ人為的に付着させた粒子，強化材表面の四凸 など，粒子の種類を問わず，いずれの場合でも同様の効果が 期待できることになる.

以上のことから，報告されている強化材周囲の PFZ層の 除去ないしは緩和を目的とする熱処理 ${ }^{(5)}$ は，MMCの強度向 上に有効である。一方で，界面上の析出物などの粒子は， PFZ が除去できない場合には，PFZによる悪影響を緩和す るため化有効である。また，㐫る程度の破断強度之剝離強度 を有する粒子で，粗大なるのが比較的低密度で分布するよら にミクロ組織を設計することが効果的である。

\section{2. 複合材料の微視的な損傷機構の検討}

粒子や短緎維で強化した金属基複合材料では，破壊の初期 段階の微視的な損傷と乙て, 強化材の破断, 界面湃離, 強化 材端部近傍の昰集中部に特计るポイドの発生等の事象が举



\section{（1）強化材の破断によるボイドの発生}

ウィスカーが破断するかどらかは，Fig. 5 で示したウィス カ一内の軸応力: $\sigma_{z}$ 之破断強度の大小関係で決まる. PFZ 層と界面粒子の形成・拡大に連れて $\sigma_{z}$ の最大值は増加し， ウィスカーの破断傾向は強まる。しかしながら, OA model で析出物サイズを変化させた計算では， $\sigma_{z}$ の変化は最大で $5 \%$ 以内である。したがって， $\sigma_{z}$ の変化主として奇与する のは，PFZ層幅であると考光られる。また， $\sigma_{z}$ の最大值は OA model で最も大きく， $\sigma_{a}=400 \mathrm{MPa}$ の段階では 3.2 $\mathrm{GPa}$ にも達する。この值は， $\mathrm{SiC} ィ$ ウィーの破断強度： $8.4 \mathrm{GPa}^{(19)}$ よりは低いものの，セラミックスからなる強化材 の破断強度は，Weibull 分布のような密度関数にしたがって 広範囲にばらつくと考光られるので，一部のウィスカーはこ の程度の応力でる破断すると考えられる。

\section{（2）界面剝離によるボイドの発生}

界面せ九断応力： $\tau_{r z}$ の最大值は, 強化材側面の端部近傍 に位置した。母相-強化材間の剝離強度 : $\tau_{i}$ を相のせえ断
降伏応力： $\tau_{y}$ 程度と考えると，次式により $\tau_{i}$ は $170 \mathrm{MPa}$ 程 度となる(11)。

$$
\tau_{y} \fallingdotseq \tau_{b}=\sigma_{b} / 2
$$

ここで，祜はせん断強度， $\sigma_{b}$ は引張強度である， $\tau_{r z}$ の絶対 值は, Basic model で $\sigma_{a}$ が $300 \mathrm{MPa}$ の段階では, 既に 180 $\mathrm{MPa}$ 程度に達して特り，十分に界面䟝離は生じ得る。しか しながら，実際の SiCウィスカ一強化6061アルミニウム合 金の破面上では，単純な界面剥離とそれに引き秸くプルアウ トは観察されず，強化材端部でのボイドの発生またはウィス カーの破断が支配的な破壊機棈であると報告されている(1). これは，実用材料の場合は強化材の配向角比分布があり， $\tau_{r z}$ が完全な一方向配向の場合よりも低いためと考克られる。

Fig. 6 では，PFZ層と界面粒子の生成により，ウィスカ 一端部近傍の析出物一強化材界面で $\tau_{r z}$ が上昇した。 したがっ て，この場合に界面剥離傾向が強まるかどらかは，析出物一



\section{（3）析出物に起因する損傷の発生}

Fig. 8 では, PA model, OA model の析出物内の応力は, 負荷応力 $250 \mathrm{MPa}$ 以上で $1 \mathrm{GPa}$ を越える高いレベルとなっ た.ただし，Weakest link 的な考光方に立てば，数十〜数 百 $\mathrm{nm}$ オーダーのサイズを持つ析出物の破断強度はかなり高 いと予測される、実際に，本研究のモデル材料を引張強度の $80 \%$ まで負荷した場合, 変形組織の TEM 観察と, MMC か ら溶出したウィスカー表面の析出物の FE-SEM 観察沈よ ば、この程度の高負荷応カレベルでも析出物の破断や剝離は 観察されて扣らず，析出物の破断強度や界面䟝離強度は予想 以上に高いものと予測された ${ }^{(20)}$. したがって, 一概に界面 析出物は䗍離し易く，容易火破断与るという憶測は当たら ず，それは合金組成や熱処理の条件と方法によると考克られ る.

\section{（4）強化材端部における母相中のボイド発生}

母相中のボイドの発生は，局所的な応力・丕みの状態によ って, 塑性歪支配, 静水王応力支配の 2 つの機構がある(21). いずれにしても，Fig. 7, Fig. 9 から，PFZ層と析出物が形 成されれば，ボイドはより早い段階から発生することにな る。また，ウィスカー強化 MMC の破壊はボイド発生支配 型子考兄られ ${ }^{(22)}$ ，変質母相に起因する早期のボイド発生は， 延性の低下に直接結び付くことになる.

ここで，ボイドの発生機構を塑性歪支配型と仮定すると， Chu 上 Needleman によれば，ボイドの発生は正規分布に従 $\zeta^{(23)}$.この場合, ボイドの発生速度: $\dot{f}$ は次式の上うに表さ れる。

$$
\begin{gathered}
\dot{f}=D \overline{\varepsilon_{p}} \\
D=f_{N} \exp \left[-1 / 2\left(\left(\overline{\varepsilon_{p}}-\varepsilon_{N}\right) / S_{N}\right)^{2}\right] / S_{N}(2 \pi)^{1 / 2}
\end{gathered}
$$

ここで， $f_{N}$ はボイドの核となる粒子の体積率， $\varepsilon_{N}$ はボイド 発生の基準となる平均昰, $S_{N}$ は標準偏差であり, 時效硬化 型アルミニウム合金では， $\varepsilon_{N} は 0.05, S_{N}$ は0.01と報告され



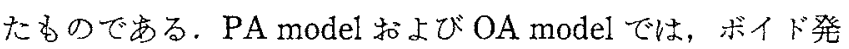






Fig. 11 Void nucleation rate, $\dot{f}$, in the matrix as a function of the applied stress.

生速度が最大となる負荷応力：㑊が, それぞれ 330 よび $350 \mathrm{MPa}$, Basic model の $390 \mathrm{MPa}$ よりもかなり低くな っている，一方，PFZ層が存在する場合でも，OA(Coarse) model のようと析出物サイズが大きなモデルでは， $\sigma_{a}^{v}=400$ $\mathrm{MPa}$ とむしろ Basic model上りもボイド発生が遅れる場 合があることが示された。

\section{（5）実験で観察される破壊機構との関連}

本研究でモデル村料とした $22 \% \mathrm{SiC}$ ウィスカー/6061Al 複合材料では, 時効処理の進行に伴って, 亜時效状態の安定 き裂成長を伴った非線形な破壊から，最高時効扣よびそれ以 降では比較的低い応力から脆性的に破壊するといった遷移が 生じることが報告されている(1)。また，微視的な破壊機構 も，亜時効状熊では強化材端部の歪子集中部でボイドが発生 ・成長する傾向が強いのに対し, 最高時效以降で, 破断し た強化材を核とするボイドの発生へと变化する(1)。

前節をでの計算 ·考察で, PFZ 層の形成と拡大化伴って, ウィスカー中の軸応力の最大值憎加した．またウウィスカ 一端部の歪及集中部に打けるボイドの発生傾向も, やはり $\mathrm{PFZ}$ 層と界面析出物の形成と拡大红伴って増加することが 明らかとなった。しかしながら，ウィスカー端部でのボイド の発生は, 界面粒子のサイズなぞによっては, むしろ PFZ や界面粒子のない場合より为抑制される場合が西ることが確 認された。したがって，上記の実験観察事実は，PFZ層や 界面析出物の形成・拡大に伴うウィスカー端部でのボイド発 生傾向の増加よりも, ウィスカー内部の軸応力の増加傾向の 方が支配的であるか，または一部の弱い析出物の破断や界面 剥離に上りウィスカー中の応力の再分布が生じ，軸応力の最 大值が上昇して，歪灭集中によるボイド発生より前の段階で ウィスカーの破断が生じる可能性を示唆していると考えられ る.

\section{3. 緩衝相となり得るInterphase に関して}

PFZのような延性的な中間層が強化材-母相間に存在する 場合, 強化材付近の応力集中が緩和されて強度が改善される という推測も, 感覚的には可能で每る。しかしながら, 本研 究の結果は, これとは全く逆に, PFZ内の優先的な塑性流 動は PFZ 以外の母相飞も広く波及し, 結果として MMCの 强度を下げる方向に㗢くことが明らかとなった。一方， Fig. 10 では, 強化材周困のいか㠴る Interphaseが, PFZ の ような軟質相ではなく，母相と強化材の中間程度の弾性率を 有する場合には，不均一变形の緩和によって相当塑性雪风が 減少し, 強度が顕著に向上することが明らかとなった。前述 のようにこのようなInterphase は, 瀻維への前処理炕上 るコーティングや強化材-母相間の化学反応に上り実現可能 である、したがって，Interphase の破壊勒性や強度は考慮 する必要が坓るものの，MMCのミク口組織制御の一指針と しては重要な知見と考完られる。

\section{V. 結 論}

ウィスカー強化アルミニウム合金基複合村料をモデル材料 とし，母相の時效析出の進行に伴って強化村周囲に形成され る幅数十 nm オーダーの PFZ 層, 界面への溶質原子の偏析, 界面上の粗大な平衡析出物の形成といった局所的に変質した 母相のミクロ組織が, 複合材料の变形・破壊挙動に及洔寸影 響を弾塑性有限要素法で解析した。

(1) PFZ 層は, 母相全体の塑性変形を促進して MMC の 強度低下を招く。一方, 界面上の析出物は, PFZ内の優先 的な塑性流動を阻止して PFZ 亿よる強度低下を抑制する方 向炕働く、ただし，PFZ層がない場合には，界面粒子火よ る強度の改善は期待できない。

（2）上記の変質組織の形成に上って，強化材内の軸応力の 最大值は增加する。強化材端の歪集中部でのボイド発生傾向 も増加するが，粒子のサイズなどに上っては，母相のミク口 組織が均一な場合上りも，か兑ってボイドの発生が抑制され ることがある。

（3） PFZ層や界面上の析出物の形成によって，界面せ儿 断応力の最大值恃上昇する。大だし, 上昇する位置は, 析出 物-強化村界面であり, この二相間の剥離強度が問題となる.

（4）界面上の粒子内部の応力は数 GPa そも達し，粒子の 破断強度は, 破壊を考光る上で重要な因子となる。ただし， 一般的なアルミニウム合金の析出物と PFZ の組合せの範团 では，粒子の弾性率が複合村料の变形・破壊に及洼す影響は 汪とえどない。

要素分割方法等で助言をいただいた豊橋技術科学大学機械 システム工学系の畔上秀幸助教授に感謝いたします。 


\section{文献}

（1）戸田裕之，小林俊郎，新家光雄：日本金属学会誌，58(1994), 468.

(2) M. Strangwood, C. A. Hippsley and J. J. Lewandowski: Scripta Metall. Mater., 24(1990), 1483.

(3) S. I. Hong, G. T. Gray III and J. J. Lewandowski: Acta metall. mater., 41(1993), 2337.

(4) D. M. Knowles and J. E. King: Mat. Sci Tech., 8(1992), 500.

(5) 戸田裕之，小林俊郎，新家光雄：日本金属学会誌，58(1994), 1086

(6) P. R. Smith, C. G. Rhodes and W. C. Revelos: Interfaces in Metal-Ceramics Composites, Ed. by R. Y. Lin et al., TMS, Pennsylvania, (1989), 35.

(7) 户田裕之, 井上直也, 新村良子, 小林俊郎 : 日本金属学会誌, $\mathbf{5 9}(1995), 925$

（8）戸田裕之，小林俊郎，新家光雄：日本金属学会誌，56(1992), 1303.

（9）戸田裕之，小林俊郎：日本金属学会誌，56(1992)，1312。

（10）戸田裕之，小林俊郎：日本金属学会誌，58(1994)，337.
（11）戸田裕之，小林俊郎，和田義治：日本金属学会誌，59(1995), 94.

（12）亚田裕之，小林俊郎，和田義治，并上直也：日本金属学会誌, 59(1995), 198.

(13) I. Dutta, J. D. Sims and D. M. Seigenthaler: Acta metall. mater., 41(1993), 885

(14) Y. Takao and M. Taya: J. Comp. Mater., 21(1987), 140

(15) R. A. Ayres: Metall. Trans. A, 10A (1979), 849.

（16）吉田英雄, 福井利安：アルミニウムの組織と性質, 㪕金属学 会, (1991), 265.

(17) E. E. Shumid, K. Oldendurg and G. Frommeyer: Z. Metallkd, $81(1990), 809$.

(18) A. D. Mcload and C. M. Gabryel: Metall. Trans. A, 23A (1992), 1423.

(19) J. J. Petrovic, J. V. Milewski, D. L. Rohr and F. D. Gac: J. Mat. Sci., 20(1985), 1167.

（20）戸田裕之，井上直也，小林俊郎：日本金属学会秋期大会宿題 テーマシンポジゥム講演概要, (1996), 73.

(21) 戸田裕之, 小林俊郎：軽金属, 45(1995), 610.

(22) J. Llorca, A. Needleman and S. Suresh: Acta Metall. Mater., $39(1991), 2317$.

(23) C. C. Chu and A Needleman: J. Engng. Mater. Tech., $102(1980), 249$. 